\title{
GAGASAN KEBANGSAAN MOHAMMAD NATSIR DAN KONTRIBUSINYA DALAM PEMIKIRAN KEISLAMAN
}

\author{
Jatim \\ STIU Al-Mujtama' Pamekasan \\ Email: jamis.mr@gmail.com
}

\begin{abstract}
Abstrak: Negara Indonesia adalah negara hukum yang berasaskan pancasila.Natsir, memandang Pancasila bagian dari nilai-nilai Islam, namun bukan berarti Pancasila adalah Islam. Islam lebih luas dari pada lima sila di dalam pancasila. Lima sila itu hanyalah menggambarkan sebagian dari ajaran Islam, tidak bisa mewakili terhadap ajaran Islam yang seutuhnya. Bagi Natsir Pancasila akan hidup subur dalam pangkuan al-Quran, maka pancasila bisa terealisir atau terlaksana dengan baik hanya dalam masyarakat dan negara yang Islami. Negara bagi Natsir adalah alat bagi umat Islam untuk merealisasikan hukum-hukum Ilahi demi keselamatan dan kesentosaan manusia. Dari sinilah Natsir, memandang perlu adanya motor penggerak untuk merealisasikan hukum-hukum Islam itu, maka Natsir menegaskan Islam dan negara adalah dua entitas relegio-politik yang menyatu. Negara bagi Natsir, bukan tujuan, tetapi alat penggerak untuk merealisasikan hukum-hukum Islam itu, namun, untuk merealisasikan hukum-hukum itu, diperlukan masyarakat yang berpendidikan dan berwawasan tinggi. Bagi Natsir Suatu negara akan maju bila masyarakatnya berpendidikan. Menurutnya pendidikan merupakan peran yang paling ampuh untuk memajukan suatu bangsa dalam mengangkat kondisi umat yang terbenam dalam lumpur keterbelakangan.
\end{abstract}

Kata Kunci: Negara, Pancasila, Islam, Pendidikan

Abstract: Indonesia is a state of law based on Pancasila. Natsir, views Pancasila as part of Islamic values, but that does not mean Pancasila is Islam. Islam is wider than the five precepts in the Pancasila. The five precepts only describe a portion of Islamic teachings, it can not represent the full teachings of Islam. For Natsir Pancasila to flourish in the fold of the Qur'an, the Pancasila can be realized or carried out well only in Islamic societies and countries. The State, for Natsir is the tool for Muslims to realize the Divine laws for the safety and tranquility of man. This is where Natsir sees the need for a driving force to realize Islamic laws, so Natsir emphasizes that Islam and the state are two unified relegio-political entities. The state for Natsir is not a goal, but a driving force for realizing Islamic laws, however, to realize those laws, an educated and high-minded society is always needed. For Natsir, a country will progress if its people are

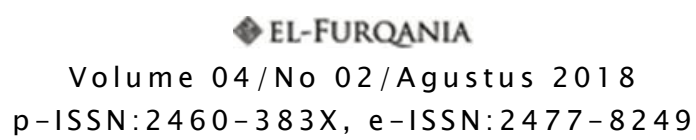


educated. According to him education is the most powerful role to advance a nation in lifting or increasing the condition of the people who are immersed in the mud of retardation.

Keywords: State, Pancasila, Islam, education

\section{Prolog}

Indonesia memiliki khazanah tokoh pembaharu dunia pendidikan Islam yang begitu banyak, para tokoh tersebut sangat intens dan menaruh perhatian besar tehadap perkembangan dan kemajuan dunia pendidikan Islam. Mereka banyak melahirkan gagasan-gagasan baru, pemikiranpemikiran yang segar bahkan gagasan-gagasan yang cemerlang yang sesuai dengan tujuan dan arahan serta visi misi pendidikan Islam. Peran tokohtokoh tersebut banyak memberikan angin segar, pencerahan ide-ide yang banyak dikembangkan oleh para praktisi pendidikan pada masa kini.

Nama Mohammad Natsir begitu penting di era pergerakan nasional dan awal kemerdekaan Indonesia.Tokoh yang di era 1930-an ini sering beradu pemikiran dengan Soekarno,iamerupakan tokoh yang selalu menginspirasi.Konsistennya memperjuangkan Negara Islam melalui Masyumi yang sudah sering kita dengar. Kali ini penulis mencoba mereview kembali pemikiran-pemikiran beliau baik kiprahnya di bidang pendidikan, dakwah ataupun dalam kenegaraan.

Beliau dikenal sebagai pahlawan nasional yang kiprahnya dalam memajukan bangsa ini, khususnya umat Islam, di waktu lampau telah diakui oleh berbagai kalangan. Bahkan, pengaruh dari usaha beliau masih dirasakan hingga sekarang. Pak Natsir (sapaan akrab beliau) tidak hanya dikenal sebagai sosok negarawan, pemikir modernis, mujahid dakwah. Tapi, beliau dikenal juga sebagai seorang aktivis pendidik bangsa yang telah menorehkan episode sejarahnya di Indonesia, sejak awal kemerdekaan hingga masa Orde Baru. Pemikirannya banyak digali dan dijadikan sebagai titik tolak kebangkitan umat Islam dalam berbagai macam bidang.

Mohammad Natsir adalah tokoh yang menggagas pembaharuan pendidikan Islam yang berbasis al-Qur'an dan al-Sunnah. Dengan berbasis al-Qur'an dan al-Sunnah, maka pendidikan Islam harus bersifat integral, harmonis, dan universal, serta mengembangkan segenap potensi manusia agar menjadi manusia yang bebas, mandiri sehingga mampu melaksanakan fungsinya sebagai khalifah di muka bumi. Konsep pendidikan yang integral, harmonis dan universal tersebut oleh Natsir dihubungkan dengan misi ajaran Islam sebagai agama yang bersifat universal. Dari latar belakang di at as maka penulis fokus pada latar belakang kehidupan Mohammad Natsir dan peranan dalam dunia pendidikan dan perpolitikan di Indonesia. 


\section{Biografi Mohammad Natsir}

Mohammad Natsir lahir di Alahan Panjang, kabupaten Solok, Sumatera Barat, 17 Juli 1908 M, wafat 6 Fepruari 1993 di Jakarta.Mohammad Natsir adalah putera daripasangan Khadijah dan Muhammad Idris Sutan Saripado, dikenal dengan sebutan Pak Natsir.Ia adalah seorang ulama, negarawan, intelektual, pembaharu, dan politikus muslim Nusantara yang disegani. Pendidikan formalnya dimulai pada usia delapan tahun, saat ia memasuki HIS Adabyah (Hollandse Inlandse School) yang didirikan tanggal 23 Agustus 1915 oleh H. Abdulah Ahmad (salah seorang tokoh pembaharu) di kota Padang. Masa pendidikan Natsir di sekolah ini tidak lama, hanya beberpa bulan,sebab iakemudian dipindahkan oleh ayahnya ke HIS pemerintah di kota Solok yang sepenuhnya mengikuti sistem pendidikan Barat (Belanda). Di sinilah fase awal interaksi Natsir dengan sistem kolonial.

Setelah lulus HIS tahun 1923, Natsir melanjutkanpendidikannya ke MULO (Middlebare Uitgebreid larger Onderwys), setingkat menengah pertama.Untuk belajar di MULO, tidak mudah karena harus memiliki beberapa persyaratan di antaranya, harus memiliki kemampuan intelektual yang memadai, mampu berbahasa Belanda, dan biasanya juga anak orang terpandang. Ketika di MULO Natsir mulai mengenal Jong Islameiten Bond (JIB)cabang Padang yang waktu itu diketuai oleh Sanusi Pane (belakangan dikenal sebagai sastrawan).

Setelah tamat di MULO, pada tahun 1927 Natsir pergi ke Bandung dan melanjutkan pendidikan formalnya di AMS (Algemene Middlebare Schoo/) setingkat sekolah menengah atas. Di sinilah Natsir mulai menekuni ilmu pengetahuan Barat, mulai dari mempelajari berbagai aspek sejarah peradaban Islam, Romawi, Yunani, dan Eropa, melalui buku-buku berbahasa Arab, Perancis, dan Latin. Di sini juga Natsir mulai bersentuhan dengan dunia yang lebih luas, baik pergaulan fisik dengan multi etnis maupun secara intelektual dengan beragam pemikiran yang berkembang waktu itu. Di usia yang begitu muda (21 tahun) Natsir telah menguasai lima bahasa asing (bahasa Arab, Belanda, Inggris, Prancis, Latin), dan dua bahasa daerah (Minangkabau dan Sunda).

Di AMS Bandung, Natsir mengenal Ahmad Hassan, seorang tokoh Islam yang bergiat di Persis, dan juga H.Agus Salim serta Ahmad Soorkati. Haji Agus Salim sebagai tokoh belajar politik bagi Natsir, sedangkan pada Ahmad Hassan ia belajar menulis dan berargumentasi. Di Persis, Natsir menjadi anggota redaksi majalah tengah bulanan Pembela Islam, yang terbit 
sejak 1929 yang kemudian dilarang terbit oleh pemerintah Kolonial pada tahun 1935 karena dianggap menyerang misi Kristen di Indonesia. ${ }^{1}$

\section{Makna Pendidikan dan Urgensinya}

Natsir berprofesi sebagai pengajar atau guru yang dimulai di sekolah MULO,ia tekuni bertahun-tahun karena ia merasa sebuah kewajiban bagi seorang muslim. Dengan berbekal pengalaman menjadi seorang guru tingkat menengah itu, Natsir kemudian mendirikan lembaga Pendidikan Islam (Pendis), yang menerapkan pola pendidikan modern dengan mengkombinasikan kurikulum pendidikan umum dengan pendidikan agama. Dalam tenggang waktu sepuluh tahun, dari tahun 1932-1942, Pendis semakin hari semakin berkembang dan semakin tumbuh subur diberbagai kota di Jawa Barat, mulai dari tingkat TK (Frobel schooI), HIS, MULO, dan Kweekschool.

Setelah bangsa Indonesia berada di bawah penjajahan bangsa Jepang, menurut Yuzril Ihza Mahendra, yang dikutip oleh Saidan dalam bukunya, bahwa sekolah-sekolah itu semuanya ditutup, sedangkan M.Natsir pindah kerja ke pemerintahan sebagai kepala biro pendidikan kota madya Bandung sampai tahun 1945 sekaligus merangkap sebagai sekretaris Sekolah Tinggi Islam (STI) di Jakarta. Menurut analisis Yusril Ihza Mahendra, itulah yang menjadi cikal bakal Universitas Islam Indonesia (UII). ${ }^{2}$

Pendidikan Islam mempunyai peranan penting dalam meningkatkan SDM. Secara ideal pendidikan Islam berfungsi untuk menyiapkan sumber daya menusia yang berkualitas tinggi baik dalam penguasaan ilmu pengetahuan dan tekhnologi maupun dalam hal karakter,sikap moral serata penghayatan dan pengamalan ajaran agama,hal ini sesuai dengan ciri pendidikan agama Islam.Pendidikan Islam yang integral tidak mengenal adanya pemisahan antara sains dan agama.Intinya pendidikan Islam,berfungsi membina dan menyiapkan anak didik yang berilmu,berteknologi,berketerampilan tinggi,sekaligus beriman dan beramal saleh.

Melihat dari konsep pendidikan Mohamad Nasir,bahwa kemajuan yang akan dicapai oleh pendidikan Islam tidaklah diukur dengan penguasaan atau supremasi atas segala kepentingan duniawi saja,akan tetapi juga melihat sampai dimana kehidupan duniawi memberiakan aset untuk kehidupan akhirat kelak.Asas pendidikan Islam menurutnya adalah

\footnotetext{
${ }^{1}$ Herry Mohammad, dkk, Tokoh-tokoh Islam yang berpengaruh abad 20 (Jakarta: Gema Insani press, 2006), 47-48; Ahmad Suhelmi, Polemik Negara Islam(Soekarno Versus Natsir) (Jakarta: TERAJU, 2002), 31-38.

${ }^{2}$ Saidan, Perbandingan pemikiran pendidikan Islam Antara Hasan al-Banna dan Mohammad Natsir (Kementerian Agama RI, 2011), 145.
} 
tauhid.Ajaran tauhid manisfestasinya adalah pembentukan kepribadian, dan merupakan tujuan dari pendidikan Islam itu sendiri. Pendidikan yang didasarkan oleh prinsip tauhid dalam rangka menghambakan diri kepada Allah SWT,terletak pada shahädah,dan shahādah dari sisi pendidikan tidak lain adalah suatu pernyataan pembebasan dari segala macam belenggu yang diciptakan oleh manusia sendiri. Pendidikan dalam Islam adalah proses yang dilakukan oleh manusia secara sadar dalam membimbing manusia menuju kesempurnaan berdasarkan Islam. ${ }^{3}$

Menurut Natsir,sisi pertama dari tauhid adalah memperkokoh kesadaran batin manusia, menumbuhkan spritualitas yang mendalam dan juga menjadi basis etika pribadi. Sedangkan sisi kedua dari tauhid adalah penekanan pada kesatuan universal umat manusia, pada umat yang satu,berdasarkan persamaan, keadilan, kasih sayang,toleransi dan kesabaran.Jadi dalam konteks kemanusiaan, tauhid menegaskan konsep humanisme universal yang tanpa batas. ${ }^{4}$

\section{Tujuan Pendidikan}

Aspek pendidikan merupakan pemikiran yang paling utama dalam pandangan Natsir.Hal ini terlihat secara ekspelisit dalam pidatonya pada saat rapat Persatuan Islam di Bogor tanggal 17 juni 1934. Dalam kesempatan itu mengatakan: "Tak ada bangsa yang terbelankang menjadi maju, melainkan sesudahnya mengadakan dan memperbaiki didikan anakanak dan pemuda-pemuda mereka. Bangsa Jepang, satu bangsa Timur yang sekarang jadi buah mulut orang seluruh dunia lantaran majunya, masih akan terus tinggal dalam kegelapan sekiranya mereka tidak mengatur pendidikan bangsa mereka; kalau sekiranya mereka tidak membukakan pintu negaranya yang selama ini tertutup rapat, untuk orang-orang pintar dan ahli-ahli ilmu, negeri lain yang akan memberikan didikan dan pengetahuan kepada pemuda-pemuda mereka di samping mengirim pemuda-pemuda mereka keluar negeri mencari ilmu". 5

Beranjak dari kutipan pidato beliau di atas, jelas alur pemikiran M.Natsir bahwa pendidikan merupakan peran yang paling ampuh untuk memajukan suatu bangsa dalam mengangkat kondisi umat yang terbenam dalam lumpur keterbelakangan.Melalui teks pidatonya, juga menggambarkan keluasan wawasan Natsir dan keterbukaan pemikiranya tentang pendidikan. Menurutnya pendidikan Islam tidak akan maju selama masih bersifat inklusif konservatif, tidak membuka pintuk untuk menerima pemikiran orang-orang pintar dari luar, sekalipun itu berasal dari orang Barat. Sebab menurut Natsir, kemunduran dan kemajuan itu, tidak

\footnotetext{
${ }^{3}$ Heri Nur Ali, Ilmu Pendidikan Islam (Jakarti: PT. Logos Wacana Ilmu, 1999), 65.

${ }^{4}$ Zakiah Derajat, Pembinaan Ahlak Remaja (Jakarta: Bumi Aksara, 1993), 65.

${ }^{5}$ Mohammad Natsir, Capita Selecta, Vol.1(Sumur Bandung, 1961), 51.
} 
tergantung pada ketimuran dan kebaratan, akan tetapi bergantung kepada ada at au tidaknya kesanggupan umat pada dunia pendidikan. ${ }^{6}$

Pikiran-pikiran Mohammad Natsir sebagian besar terkumpul dalam buku Capita Selecta, terutama tentang pendidikan.Didalamnya menyebutkan tentang makna pendidikan yang diurai oleh Natsir dengan bahasa yang sederhana, namun memukau.Menurut Natsir yang dinamakan didikan adalah suatu pimpinan jasmani dan rohani yang menuju kepada kesempurnaan sifat-sifat kemanusiaan, dengan arti yang sesungguhnya.Natsir melihat pendidikan sebagai usaha untuk mengisi nilainilai positif baik bagi jasmani maupun rohani yang menuju kepada terwujudnya manusia yang ideal (insan kamil).Menurutnya tujuan pendidikan adalah sama dengan tujuan hidup manusia didunia ini. Dari sini Nampak jelas bahwa Natsir tidak membedakan antara tujuan pendidikan dengan tujuan diciptakanya manusia.

Fungsi pendidikan Islam menurut Mohammad Natsir, menjadikan manusia yang memperhambakan segenap rohani dan jasmaninya kepada Allah SWT.Hal ini sesuai dengan konsep Islam terhadap manusia itu sendiri.Bahwa mereka diciptakan oleh Allah untuk menghambakan diri hanya kepada Allah semata. Oleh karenanya segala usaha dan upaya manusia harus mengarah pada tujuan akhir pendidikan Islam, Sebagaimana ia mengukutip al-Quran surahal-Dhāriāt ayat:56, وما خلقت الجن والإنس الا (ليعبدون (Dan Aku tidak menciptakan jin dan manusia melainkan supaya mereka menyembah-Ku".

Natsir menjadikan ayat itu sebagai sebuah argumentasi tentang pentingnya manusia memiliki ideologi untuk menjadi hamba Allah yang sesungguhnya.Tujuan pendidikan Islam yang ingin dicapai oleh Mohammad Natsir adalah membentuk manusia yang beriman, bertaqwa, berakhlak mulia, maju dan mandiri, sehingga memiliki ketahanan rohaniah yang tinggi serta mampu beradaptasi dengan dinamika perkembangan masyarakat.Selain itu bahwa tujuan manusia adalah untuk mendapatkan kebahagiaan hidup di dunia dan akhirat. ${ }^{7}$

\section{Karakter Pendidikan Islam}

karakter pendidikan Islam disini adalah ciri-ciri khusus yang terdapat dalam pendidikan tersebut. Kekhasan tersebut menurut Mohamad Natsir ada pada beberapa hal berikut ini:

a. Universal

Pendidikan dengan sifat seperti ini diuraikan Natsir dalam bentuk penerimaan sumber datangnya ilmu antara Timur dan Barat.Disini Natsir

\footnotetext{
${ }^{6}$ Ibid., 52.

${ }^{7}$ Saidan, Perbandingan pemikiran pendidikan Islam Antara Hasan al-Banna dan Mohammad Natsir :218-219; Mohammad.Natsir, Capita Selecta: 56.
} 
tidak membedakan antara ilmu timur dan ilmu barat.Menurut Natsir sesungguhnya antara Barat danTimur adalah sama,dimana kedua-duanya adalah makhluk Allah yang bersifat baru. Bagi Natsir Islam hanya membedakan antara haq dan bätil. Begitu pula halnya kemajuan dan kemunduran, tidaklah tergantung dari ketimuran dan kebaratan,dan tidak pula pada putih,kuning atau hitamnya warna kulit,tetapi tergantung pada ada atau tidaknya sifat-sifat dan bibit-bibit dalam salah satu umat,yang menjadikan mereka layak atau tidaknya menduduki tempat yang mulia diatas bumi ini.

b. Integral

Artinya pendidikan tidak mengenal pemisahan antara jasmani dan rohani,serta dunia dan akhirat. Sehingga pendidikanIslam itu mengantarkan seseorang pada kebahagiaan didunia maupun akhirat. Mengenai sifat pendidikan yang integral ini Natsir memahami bahwasannya pendidikan itu mesti memiliki nilai-nilai keseimbangan jasmani dan rohani, dunia dan akhirat bukanlah dua hal yang bertentangan yang harus dipisahkan,melainkan dua hal serangkai yang saling melengkapi dan melebur menjadi satu susunan yang harmonis dan seimbang. ${ }^{8}$

\section{Perjuangan Politik}

Mohammad Nasir adalah seorang demokrat sejati, ia memulai karir politiknya dengan mendaftarkan diri menjadi anggota Partai Politik Islam (PII) pada tahun 1938. Pada tahun 1940-1942 berkat perjuangannya, ia diangkat sebagai ketua partai cabang di Bandung, ia juga diangkat sebagai abdi negara oleh pemerintah sebagai kepala biro pendidikan kota madya Bandung sampai 1945, sekaligus merangkap sebagai sekretaris Sekolah Tinggi Islam (STI) di Jakarta. Puncak karir politiknya adalah menjadi anggota Komite Nasional Indonesia Pusat (KNIP), ketua partai Masyumi, Menteri Penerangan, dan juga pernah menjadi Perdana Menteri RI pada pemerintahan Soekarno.Ketika Sutan Syahrir duduk sebagai perdana meteri, ia memerlukan figur Islam yang mensosialisasikan program-program kabinetnya. Maka dipilihlah Natsir sebagai Menteri Penerangan.Dialah, menteri penerangan pertama di republik ini. Jabatan sebagai menteri penerangan ia pegang sebanyak tiga kali, dua kali dalam kabinet Syahrir dan satu kali dalam kabinet Hatta. ${ }^{9}$

M.Natsri tidak saja dikenal sebagai seorang yang punya andil dalam memperjuangkan kemerdekaan Indonesia, akan tetapi lebih dari itu, ia berkiprah dalam mempertahankan Negara Kesatuan Republik Indonesia

\footnotetext{
${ }^{8}$ Mohammad Natsir, Capita Selecta : 52.

${ }^{9}$ Herry Mohammad, dkk, Tokoh-tokoh Islam yang berpengaruh abad 20:48- 49; Saidan, Perbandingan pemikiran pendidikan Islam Antara Hasan al-Banna dan MohammadNatsir :55-59.
} 
(NKRI) dengan mosi integral. Pada tahun 1950 Natsir mengangkat mosi pada sidang parlemen Republik Indonesia Serikat (RIS) yang dikenal dengan mosi integral Natsir.Mosi ini adalah menyatukan republik Indonesia yang telah terpecah belah menjadi beberapa negara bagian, ini sebagai akibat dari Konferensi Meja Bundar (KMB), kemudian kembali kepada pangkuan negara Kesatuan Republik Indonesia (NKRI). Oleh karena mosi inilah, kemudian ia dapat tampil pada puncak pemerintahan. ${ }^{10}$

Pada tahun 1958, Natsir dianggap terlibat dalam Pemerintahan Repolusioner Republik Indonesia (PRRI), yang dibentuk di Sumatera Barat.Pemerintahan tandingan ini dimunculkan sebagai reaksi dan protes atas kebijakan Soekarno yang telah menyeleweng dari UUD 1945, bukan karena ingin mengambil kekuasaan.PRRI itu bermula ketika Soekarno mengangkat dirinya sebagai formatur kabinet, padahal sistem politik saat itu adalah sistem demokrasi parlementer.Namun akhirnya PRRI ini berhasil dilumpuhkan oleh meliter atas perintah pemerintah pusat.Akibat dari keterlibatannya dalam gerakan itu, maka, pada tahun 1960 ia di tangkap dan di jebloskan kedalam penjara. Pada tahun yang sama, Masyumi dibubarkan, karena PRRI didominasi oleh anggota Masyumi. Pada tahun 1966, M.Natsir dibebaskan dari penjara setelah pemerintahan dipegang oleh Orde Baru.Sejak itulah, perjuangan politik M.Natsir berakhir. ${ }^{11}$

\section{Gagasan Dan Gerakan}

\section{Islam Dan Negara}

\section{a. Dasar Negara}

Berbicara tentang hubungan Islam dan negara, M.Natsir menjadi pembela utama dalam paham penyatuan agama dan negara. Bagi Natsir, Islam tidak hanya terdiri dari praktik-praktik ibadah, melainkan juga prinsip-prinsip umum yang relevan untuk mengatur hubungan antara individu dan masyarakat. ${ }^{12}$ Meskipun demikian, Natsir amat menyadari bahwa al-Quran dan al-Sunah tidak punya "tangan dan kaki" untuk membuat manusia berjalan sesuai dengan aturan-aturan Islam.Oleh karena itu, Natsir memandang bahwa perlu adanya alat yang cocok agar hukumhukum Islam bisa dijalankan.

Dari sinilah Natsir, memandang perlu adanya motor penggerak untuk merealisasikan hukum-hukum Islam itu, maka Natsir menegaskan

\footnotetext{
${ }^{10}$ Muridan, “ Jurnal Dakwah dan Komunikasi: Gagasan Pemikiran dan Gerakan Dakwah M.Natsir di Indonesia", KOMUNIKA, Vol. 3, No. 1 Juni 2009; Indah Muliati, "Pandangan M.Natsir tentang Demokrasi: Makalah Universitas Negri Padang, (April 2012), 3-4.

${ }^{11}$ Didin Saefuddin, Pemikiran Modern dan Post Modern Islam (Jakarta: Gramedia Widia Sarana Indonesia, 2003), 214; Indah Muliati, "Pandangan M.Natsir tentang Demokrasi: 5-6.

${ }^{12}$ Mohammad Natsir, Capita Selecta, Vol. 2, 201.
} 
Islam dan negara adalah dua entitas relegio-politik yang menyatu. Negara bagi Natsir, bukan tujuan, tetapi alat. Urusan kenegaraan pada pokoknya dan pada dasarnya adalah satu bagian yang tak dapat dipisahkan dari Islam, ${ }^{13}$ lain halnya dengan Soekarno yang menginginkan pemisahan agama dari negara, karena memandang agama merupakan urusan spiritual dan pribadi, sedangkan masalah negara adalah persoalan dunia dan kemasyarakatan. Soekarno menganggap campur tangan negara terhadap urusan agama, tidak saja akan merusak kehidupan kaum muslimin, tetapi juga negara atau pemerintah yang bersangkutan. ${ }^{14}$

Pada tahun 1940-an Natsir pernah terlibat polemik dengan Soekarno, tentang agama dan negara. Menurut Soekarno agama harus dipisahkan dari negara. Pandangannya itu, ia kutip dari Syekh Ali Abdur Raziq, seorang ulama dari Universitas Al-Azhar Kairo, Mesir, bahwa keharusan bersatunya negara dengan agama tidak ada dasarnya dalam syariat Islam, baik itu al-Quran dan al-sunah, maupun ijma' ulama, sebab tugas Nabi Muhammad saw yang terpokok adalah menegakkan syiar Islam tanpa bermaksud mendirikan negara.Soekarno lalu menengok ke Turki, dimana Mostafa Kamil Attartuk, memisahkan agama dari negara.Dan menurut Soekarno karena itu Turki bisa maju.

Tapi, bagi Natsir, pemikiran Soekarno itu keliru, ia menilai gagasan pemisahan agama dari negara yang dikemukakan Soekarno merupakan menyimpangan (distorsi) sejarah Islam. Natsir, berkeyakinan bahwa dalam sejarah Islam tidak pernah dikenal adanya paham pemisahan agama dari negara.Menurutnya agama dalam hal ini Islam,tidak dapat dipisahkan dari negara.Ia mengatakan bahwa urusan kenegaraan pada pokoknya merupakan bagian dari integral dari risalah Islam. ${ }^{15}$ Dinyatakan pula bahwa kaum muslimin mempunyai falsafah hidup atau ideologi seperti kalangan Kristen, fasisme atau komunisme. Natsir lalu mengutip nash alQuran yang dianggap sebagai dasar ideologi Islam, dalam surah alDhāriyātayat 56, artinya: "Tidak Aku jadikan jin dan manusia melainkan untuk mengabdikepada-Ku". Bertitik tolak dari dasar ideologi Islam inilah, ia berkesimpulan bahwa cita-cita hidup seorang muslim di dunia ini hanya ingin menjadi hamba Allah agar mencapai kejayaan dunia dan akhirat kelak.Untuk mencapai predikat hamba Allah, maka Allah memberikan aturan kepada manusia bagaimana berhubungan dengan Allah dan berhubungan dengan sesama manusia (mahluk).Hubungan yang kedua inilah, yang di namakan dengan urusan kenegaraan. ${ }^{16}$

${ }^{13}$ Bahtiar Effendy, Islam dan Negara (Transformasi Pemikiran dan Praktik Politik Islam di Indonesia) (Jakarta: Paramadina, 1998), 79-80.

${ }^{14}$ Ahmad Suhelmi, Polemik Negara Islam(Soekarno Versus Natsir): 94.

${ }^{15}$ Herry Mohammad, dkk, Tokoh-tokoh Islam yang berpengaruh abad 20): 49 ; Ahmad Suhelmi, Polemik Negara Islam(Soekarno Versus Natsir): 82.

${ }^{16}$ Ahmad Suhelmi, Polemik Negara Islam(Soekarno Versus Natsir): 87. 
Terlepas dari itu, perlu dicatat bahwa Natsir juga mengakui dalam semua hal di atas, Islam hanya memberikan prinsip-prinsip umum.Aturanaturan yang lebih terperinci mengenai bagaimana sebuah negara harus diorganesasikan atau dijalankan, tergantung pada kemampuan para pemimpinnya untuk melakukan ijtihăd, dengan syarat semuanya dilakukan secara demokratis. Dengan cara demikianlah tambahnya, tantangantantangan modernitas dapat terjawab. Dari pernyataan itu, ia menolak pandangan bahwa Islam menentang paham kemajuan. ${ }^{17}$

b. Eksistensi Negara

Bagi nasir negara adalah alat bagi umat Islam untuk merealisasikan hukum-hukum Ilahi demi keselamatan dan kesentosaan manusia. Seperangkat hukum-hukum saja, bagaimanapun kelebihan yang di mililikinya, tidak akan mampu menciptakan masyarakat yang adil dan sejahtera, kalau meminjam istilah al-Quran, baldatun țayyibatun wa rabbun ghafü.Agar hukum-hukum tersebut mampu menjamin dan membentuk masyarakat yang ideal, maka diperlukan adanya kekuatan eksekutif atau pelaksana.Kekuatan eksekutif tersebut adalah negara.

Di sinilah arti pengtingnya lembaga negara sebagai alat untuk menerapkan hukum-hukum yang telah ada.tanpa adanya negara sulit diharapkan adanya ketaatan pada hukum-hukum itu. Jalan pikiran seperti ini yang nampaknya menguasai pandangan Natsir tentang negara sebagai alat untuk menjalankan hukum-hukum Allah.Natsir dalam merealisasikan hukum-hukum Islam dalam masyarakat menekankan pada pendekatan legal formal, berbeda dengan Soekarno yang lebih menekankan pendekatan sosialisasi dalam pelaksanaan ajaran Islam di kalangan warga negara atau masyarakat. ${ }^{18}$ Bagi Natsir negara bukanlah menjadi tujuan akhir, tetapi hanyalah alat untuk merealisasikan atura-aturan Islam yang terdapat dalam al-Qur'an dan al-Sunah.Tujuan yang sesungguhnya adalah berlakunya undang-undang Ilahi secara sempurna dalam kehidupan manusia baik secara individu maupun bermasyarakat dan bernegara. ${ }^{19}$

c. Politik Sebagai Media Dakwah

Menurut Nastir, modernisasi politik Islam merupakan sikap dan pandangan yang berusaha menerapkan ajaran dan nilai-nilai kerohanian Islam yang terkandung dalam al-Quran dan al-sunah, yang disesuaikan dengan perkembangan-perkembangan mutakhir dalam sejarah peradaban manusia. Dalam terma politik inilah, ia mewajibkan setiap umat Islam untuk berpolitik sebagai sarana dakwah Islam.

${ }^{17}$ Bahtiar Effendy, Islam dan Negara (Transformasi Pemikiran dan Praktik Politik Islam di Indonesia): 81.

${ }^{18}$ Ibid., 123.

${ }^{19}$ Herry Mohammad, dkk, Tokoh-tokoh Islam yang berpengaruh abad 20 : 49-50; Abdul munir Mulkhan, Ideologisasi Gerakan Dakwah Episod Kehidupan M.Natsir dan Azhar Basyir (Yogyakarta: Sippress, 1996), 193. 
Politik sebagai sarana dakwah, berarti aturan-aturan main politik itu harus paralel dengan aturan main dakwah.Hal ini juga berarti politik tidak boleh menyesatkan, tidak boleh menjungkir-balikkan kebenaran, dan mengelabuhi masyarakat. Selain itu, keterbukaan, kejujuran, rasa tanggung jawab, serta keberanian untuk menyatakan yang benar itu adalah benar, dan yang batil itu adalah batil, harus menjadi ciri politik yang berfungsi sebagai sarana dakwah.

Dengan memiliki ciri-ciri di atas, politik baru akan fungsional tujuan dakwah. Sebaliknya, jika aturan main politik tidak sejalan dengan aturan main dakwah, maka dapat diperkirakan bahwa politik semacam itu akan disfunfsional terhadap dakwah. ${ }^{20}$ Politik yang dijalankan oleh seorang Islam, berfungsi sebagai sarana dakwah, bukanlah politik yang sekuler, melainkan politik yang penuh komitmen pada Allah. Dalam hal ini, politik bukan menjadi tujuan utama untuk mencari kekuasaan demi kekuasaan atau kepentingan demi kepentingan belaka.

d. Islam Dan Pancasila

Natsir telah menjelaskan panjang lebar hubungan Pancasila dengan Islam dalam pidato memperingati Nuzulul Quran, Ramadhan $1373 \mathrm{H} . / \mathrm{Mei}$ 1954 M. Dengan tema "Apakah Pancasila bertentangan dengan ajaran AlQur'an?"Natsir, memandang Pancasila bagian dari nilai-nilai Islam, namun bukan berarti Pancasila adalah Islam.Islam lebih luas dari pada lima sila di dalam pancasila. Lima sila itu hanyalah menggambarkan sebagian dari ajaran Islam, tidak bisa mewakili terhadap ajaran Islam yang seutuhnya.Inti Pancasila menurutnya adalah sila pertama yang merupakan urat tunggal bagi sila-sila berikutnya.Masih menurut Natsir bahwa dalam pangkuan AlQuran Pancasila akan hidup subur.Pancasila dalam pandangan Natsir bisa terealisir atau terlaksana dengan baik hanya dalam masyarakat dan negara yang Islami.

Natsir menguraikan Sila itu satu persatu tentang hubungan nya dengan Al-Quran, Sila pertama "Ketuhanan Yang Maha Esa" adalah pancaran tauhid, Sila kedua "Kemanusiaan Yang Adil dan Beradab" merupakan salah satu unsur utama dari nilai-nilai keadilan sosial masyarakat dalam Islam, Sila ketiga "Persatuan" merupakan satu sendi ajaran Islam yang berupa ukhuwah Islamiyah, Sila keempat "Kerakyatan yang dipimpin oleh hikmat, kebijaksanaan dalam permusyawatan perwakilan", di dalam al-Quran telah dijelaskan dalam setiap keputusan agar melalui musyawarah "Washāwirhum fi al-amri",dan Sila yang terakhir "Keadilan Sosial" menjadi sasaran pembentukan masyarakat marhamah menurut Islam, yang harus dipraktekkan dengan perasaan kasih dan sayang, sehinggatercipta sebuah negara yang Baldatun Tayyibatun warabbun

\footnotetext{
${ }^{20}$ Yuzril Ihza Mahendra, Modernisme dan Fundamentalisme dalam Politik Islam (Jakarta: Paramadina, 1999), 136.
} 
Ghafür.Namun di akhir pidatonya itu, Natsir juga mengatakan agar dalam pelaksanaan Pancasila itu tidak dijadikan penghalang bagi terlaksananya kaidah-kaidah dan ajaran-ajaran yang termaktub dalam al-Quran yang merupakan induk dari Pancasila itu. ${ }^{21}$

\section{Gerakan Dakwah}

Telah diuraikan di atas bahwa perjuangan politik M.Natsir berakhir pada tahun 1960, setelah ia dijebloskan ke penjara oleh Soekarno. Baru setelah runtuhnya Orde Lama dan digantikan oleh Orde Baru, pada tahun 1966, M.Natsir dibebaskan oleh Soeharto. Mulai saat itulah M.Natsir mengubah gerakannya dari gerakan politik kepada gerakan dakwah.

Dakwah adalah pekerjaan atau ucapan untuk mempengaruhi manusia mengikuti Islam.Dakwah juga di artikan sebagai aktivitas mengajak dan menggerakkan manusia agar mentaati ajaran Islam dengan melaksanakan Amar Ma'ruf Nahi Mungkar, untuk dapat memperoleh kebahagian hidup di dunia dan akhirat. Dari pengertian di atas, secara substansial, dakwah dapat diartikan sebagai sebuah proses penyampaian ajaran Islam kepada umat manusia, dalam bentuk Amar Ma'ruf Nahi Mungkar, dan keteladanan yang baik dalam kehidupan sehari-hari dengan menggunakan metode yang sesuai dengan kebutuhan masyarakat agar dapat mencapai kebahagiaan dunia dan akhirat.

Dakwah merupakan sebuah kegiatan atau akitivitas untuk membentuk komunitas, dan masyarakat, serta peradaban manusia yang mengantarkan kepada cita-cita ideal dakwah, yaitu terwujudnya Khaira Ummah.Sebab itulah, menurut M.Natsir, dakwah harus berpijak pada rasa cinta dan persaudaraan. Lebih lanjut M.Natsir menegaskan bahwa dakwah memiliki tujuan yang sangat mulia yaitu:

a. Memanggil kita kepada syariat untuk memecahkan persoalan-persoalan hidup, baik persorangan, keluarga, masyarakat, bangsa dan negara.

b. Memanggil kita pada fungsi hidup sebagai hamba Allah di muka bumi yang terbentang luas, berisikan manusia berbagai jenis, berbagai pola pendirian, dan kepercayaan, yakni sebagai fungsi huhadà' alā al-nās, menjadi pelopor dan pengawas bagi umat manusia.

c. Memanggil kita kepada tujuan hidup kita yang hakiki, yaitu menyembah Allah. ${ }^{22}$

\section{Mendirikan Lembaga DakwahDDII}

Di awal pemerintahan Soeharto yang dikenal dengan istilah Orde Baru, M.Natsir bersama kawan-kawan seperjuangannya selalu gigih memperjuangkan agar Masyumi kembali hidup. Berbagai usaha dan lobi-

${ }^{21}$ Mohammad Natsir, Capita Selecta, Vol.2: 273-285.

${ }^{22}$ Didin Saefuddin, Pemikiran Modern dan Post Modern Islam: 220. 
lobi di tingkat tinggi ia lakukan, akan tetapi selalu kandas, karena kalangan ABRI sendiri merasa keberatan. Hal itu menurut analisis Thohir Luth, karena keterlibatan tokoh-tokoh Masyumi dalam pemberontakan PRRI, semisal M.Natsir sendiri. Oleh karena itu, M.Natsir bersama tokoh-tokoh lainnya mencari jalan lain dengan meninggalkan dunia politik dan beralih memasuki dunia dakwah.

Pada 26 Februari 1967, beserta ulama, tokoh-tokoh politik dan tokoh-tokoh agama, khususnya mantan akitivis Masyumi, membicarakan persoalan-persoalan yang dihadapi umat Islam di Indonesia.Dari pembicaraan tersebut, disepakati bahwa untuk memperjuangkan Islam diperlukan lembaga yang mewadahinya. Pada 6 Mei 1967 dibentuklah lembaga dakwah yangdiberi nama Dewan Dakwah Islamiah Indonesia (DDII). Lembaga ini dibentuk dengan tujuan untuk mendorong, memperbaiki, dan mengembangkan dakwah Islamiah di Indonesia dengan dasar takwa dan keridhaan Allah SWT.

Melalui DDII, M.Natsir mengembangkan dakwah Islamiah dengan tiga pilar penting, yaitu masjid, pondok pesantren, dan kampus. Pertama, masjid adalah lembaga risalah, tempat mencetak umat yang beriman, beribadah, tempat menghubungkan jiwa manusia dengan khaliknya, tempat mencetak umat yang beramal shaleh dalam kehidupan masyarakat, dan tempat mencetak umat yang berakhlakul karimah. Dari masjid inilah diharapkan akan lahir jamaah yang kuat dan solid bukan hanya dalm bidang akidah dan ibadah, tetapi juga muamalah. Kedua,pondok pesantren, dari pondok pesantren ini diharapkan akan lahir ulama yang mempunyai kometmen dan semangat yang kuat mendakwahkan Islam keseluruh tanah air. Ketiga, kampus, dari kampus inilah diharapkan akan lahir cendekiawan, dan pemimpin diberbagai lapangan kehidupan.

Sebagaimana organisasi yang lain, DDII memiliki cabang di berbagai daerah, baik di tingkat propensi maupun kabupaten yang tersebar di seluruh Indonesia. DDII sendiri memiliki kantor pusat di Jl.Kramat Raya No.5 Jakarta dan memiliki masjid yang diberi nama Al-Furqan.

Perpaduan ketiga pilar dakwah ini seharusnya bukan hanya perpaduan fisik, tetapi juga persepsi, pemikiran, dan amaliah. Dengan kata lain, kaum cendikiawan dan civitas akademika di kampus harus memahami pesantren dan masjid. Kaum santri harus memahami kampus dan masjid. Jika kekuatan ini bersatu, niscaya akan menjadi modal besar bagi pembinaan umat maupun pembangunan bangsa dan negara.

Sebagai ketua DDII, M.Natsir juga mengembangkan dakwah dengan menyediakan tenaga khatibdan muballihg disejumlah masjid di Jakarta. Para khatib dan muballigh ini sebelum diterjunkan kelapangan diberikan arahan terlebih dahulu, agar ketika menyampaikan ajaran Islam hanya berpegangan pada al-Quran dan al-Sunah saja, tanpa terikat dan taklid terhadap madzhab tertentu. Hal ini dilakukan untuk mengantisipasi 
ajaran-ajaran yang menyimpang agar umat yang menjadi sasaran dakwah tidak sesat.

Selain menyediakan khatib dan muballigh, DDII juga mengelola penerbitan, percetakan, toko buku, dan lembaga pendidikan, serta menerbitkan majalah Islam seperti: buletin dakwah, majalah serial khatbah jumat, suara masjid, serial media dakwah, dan majalah anak-anak sahabat.Buku-buku Islam juga diterbitkan seperti buku-buku karya M.Natsir atau buku-buku anggota DDII yang lainnya.Baik karya sendiri maupun terjemahan.

Untuk meningkatkan kualitas sumberdaya manusia (SDM), DDII kemudian merekomendasikan kepada siswa-siswi atau santri untuk melanjutkan pendidikan, khususnya ke Timur Tengah.Sebagian dari mereka diberikan beasiswa dari DDII dan sebagian lagi mendapatkan beasiswa dari negara-negara Timur Tengah melalui DDII. ${ }^{23}$

\section{Epilog}

Negara Indonesia adalah negara hukum yang berasaskan Pancasila.Natsir, memandang Pancasila bagian dari nilai-nilai Islam, namun bukan berarti Pancasila adalah Islam. Islam lebih luas dari pada lima sila di dalam pancasila. Lima sila itu hanyalah menggambarkan sebagian dari ajaran Islam, tidak bisa mewakili terhadap ajaran Islam yang seutuhnya. Bagi Natsir Pancasila akan hidup subur dalam pangkuan al-Quran, maka pancasila bisa terealisir atau terlaksana dengan baik hanya dalam masyarakat dan negara yang Islami. Negara bagi Natsir adalah alat bagi umat Islam untuk merealisasikan hukum-hukum Ilahi demi keselamatan dan kesentosaan manusia. Dari sinilah Natsir, memandang perlu adanya motor penggerak untuk merealisasikan hukum-hukum Islam itu, maka Natsir menegaskan Islam dan negara adalah dua entitas relegio-politik yang menyatu. Negara bagi Natsir, bukan tujuan, tetapi alat penggerak untuk merealisasikan hukum-hukum Islam itu, namun, untuk merealisasikan hukum-hukum itu, diperlukan masyarakat yang berpendidikan dan berwawasan tinggi. Bagi Natsir Suatu negara akan maju bila masyarakatnya berpendidikan. Menurutnya pendidikan merupakan peran yang paling ampuh untuk memajukan suatu bangsa dalam mengangkat kondisi umat yang terbenam dalam lumpur keterbelakangan.

\footnotetext{
${ }^{23}$ Muridan, “ Jurnal Dakwah dan Komunikasi: Gagasan Pemikiran dan Gerakan Dakwah M.Natsir di Indonesia", KOMUNIKA, Vol. 3, No. 1 Juni 2009 ; Saidan, Perbandingan Pemikiran Pendidikan Islam Antara Hasan al-Banna dan Mohammad Natsir : 154-156.
} 
Gagasan Kebangsaan Mohammad Natsir Dan Kontribusinya Dalam Pemikiran Keislaman

\section{Daftar Pustaka}

Derajat, Zakiah. Pembinaan Ahlak Remaja. Jakarta: Bumi Aksara, 1993.

Effendy, Bahtiar. Islam dan Negara: Transformasi Pemikiran dan Praktik Politik Islam di Indonesia. Jakarta: Paramadina, 1998.

Mohammad, Herry, dkk.Tokoh-tokoh Islam yang berpengaruh abad 20.Jakarta: Gema Insani press, 2006.

Muridan.Jurnal Dakwah dan Komunikasi: Gagasan Pemikiran dan Gerakan Dakwah M.Natsir di Indonesia”, KOMUNIKA, Vol. 3, No. 1 Juni 2009.

Muliati, Indah. "Pandangan M.Natsir tentang Demokrasi: Makalah Universitas Negri Padang, (April 2012 ).

Munir, Abdul Mulkhan. Ideologisasi Gerakan Dakwah Episod Kehidupan M.Natsir dan Azhar Basyir .Yogyakarta: Sippress, 1996.

Mahendra,Yuzril Ihza.Modernisme dan Fundamentalisme dalam Politik Islam. Jakarta: Paramadina, 1999.

Natsir, Mohammad.Capita Selecta. Sumur Bandung, 1961.

Nur, Heri Ali. Ilmu Pendidikan Islam.Jakarta: PT. Logos Wacana Ilmu, 1999.

Suhelmi, Ahmad. Polemik Negara Islam: Soekarno Versus Natsir. Jakarta: TERAJU, 2002.

Saidan.Perbandingan pemikiran pendidikan Islam Antara Hasan al-Banna dan Mohammad Natsir.Kementerian Agama RI, 2011.

Saefuddin, Didin. Pemikiran Modern dan Post Mudern Islam.Jakarta: Gramedia Widia Sarana Indonesia, 2003. 